\title{
Adjusting to Really Big Changes: The labor market in China, 1989-2009
}

\author{
Wei Chi \\ School of Economics and Management, Tsinghua University \\ Richard Freeman \\ Harvard University and NBER \\ Hongbin Li \\ School of Economics and Management, Tsinghua University
}

\begin{abstract}
:
China's emerging labor market was buffeted by changes in demand and supply and institutional changes in the last two decades. Using the Chinese Urban Household Survey data from 1989 to 2009, our study shows that the market responded with substantial changes in the structure of wages and in employment and types of jobs that workers obtained that mirrors the adjustments found in labor markets in advanced economies. However, the one place where the Chinese labor market appears to diverge from the labor markets in advanced countries is the rapid convergence in earnings and occupational positions of cohorts who entered the job market under more or less favorable conditions. On this dimension, China's labor market seems more flexible than those in other countries. Three related factors may explain this pattern: (1) the rapid growth of China's economy; (2) the high rate of employee turnover; (3) the relative weakness of internal labor markets in China. Bottom line, the Chinese labor market has responded about as well as one could expect to the changes in the demand and supply factors and institutional shocks in this critical period in Chinese economic history.
\end{abstract}

JEL classification code: J3

Key words: Chinese labor market; supply and demand factors; earnings dispersion; occupation position; cohort effect 
Until China began its post-Mao economic reforms, the country did not have a genuine labor market. State owned enterprises were the only source of demand for labor. Administrative agencies assigned workers to firms, so individual choice did not determine labor supply. Then China began the process of transitioning from a state-run economy to a more market-driven one. The early reforms focused on agriculture and product markets but slowly the government freed firms to make labor demand decisions and freed workers to choose their own places of work, creating a genuine labor market. How did this emergent labor market respond to shifts in the supply and demand for labor as China's urban economy grew rapidly?

This paper uses data from the National Bureau of Statistics' (NBS) Urban Household Survey1 from 1989 through 2009, which covers the period when China's labor market developed, to examine how the emergent labor market altered China's wage structure and occupations attained by workers with different levels of schooling. It develops a pooled cross-province time series data set from the NBS files to assess market responses to shifts in supply and demand. We find that:

(1) Replacing administrative decisions with market wage determination widened the wage structure along several dimensions. Educational earnings differentials increased, then stabilized. Experience differentials fell through 1990, then rose. The dispersion of earnings grew massively, especially for older workers whose pay had been constrained during the years of administrative rule.

(2) The wages and employment of young workers varied with the market conditions when they

$1 \quad$ NBS has conducted the Urban Household Survey yearly since 1986. The aggregate statistics are published in China Statistical Yearbooks. The NBS urban household surveys use a stratified two-stage random sampling method. In the first stage, NSB selects cities and counties according to population size to ensure the sample is representative of the urban population. In the second stage, within each selected location, the survey samples sub-districts (street committees), resident committees, and households successively. Each year 1/3 of the households from the second stage are rotated out and replaced by new households, so that the sample is renewed every 3 years. The NBS urban household survey begins with items on the individual's demographic and employment status, followed by various month-end income forms. The rest of the survey records information on the household's daily expenditure. Local NBS offices collect the data, which is then aggregated into the annual data. The NBS urban household surveys did not ask about hours of work until 2002, so we could not calculate the hourly wage rate and instead used annual earnings. Unlike the U.S. Current Population Survey, the NBS asks respondents the year when they start working, which allows us to identify different entry cohorts of workers. 
first sought work, much as the wages and employment vary with business cycles in the US and other advanced countries. But whereas in those countries cohort effects persist for over a decade, in china cohort effects associated with the supply/demand balance diminished within three years.

(3) Direct measures of supply and demand factors impacted the wage structure. Higher cohort sizes reduced earnings and increased the dispersion of earnings, largely for starting graduates. Rising GDP raised the level and dispersion of earnings, again more for starting graduates than for more experienced workers. But the labor market also adjusted to change with changes in the rate of joblessness and changes in the occupational position of workers with given years of education.

Overall, the adjustments in China to changes in supply and demand are similar to those in the US (which faced more modest market pressures) while the decay of cohort differentials suggests greater wage flexibility in China.

\section{Transition to Genuine Labor Market}

We start our analysis with a brief summary of the economic reforms that created a functioning labor market in China.

Prior to the reforms state owned enterprises (SOE) employed nearly all urban workers. Enterprises could not lay off workers and rarely discharged them for poor performance, effectively creating "iron rice bowl" life-time employment. The state assigned workers to jobs in work units and did not permit them to change jobs on their own accord. The labor bureau used the same wage grid to determine workers' salaries across enterprises, industries and regions. The grid included 8 grades for blue-collar workers and 24 grades for white-collar including professional, technical, and managerial employees. The wage differences across enterprises, industries and regions, were small. The state set wages at a low level, but work units provided benefits to employees such as free housing, pension, child care, and medical service. Individual SOEs paid retirees the same salaries as when they were working. The wage structure was highly compressed. 
In the 1980s, the central government loosened its grip on the labor market. It allowed SOEs to set wages for their employees though the government still controlled the total payroll. It allowed SOEs to fire employees who did not perform adequately, though SOE jobs remained more secure than jobs in private or foreign and joint ventures. Passage of “the CPC's Resolution on Economic Institutional Reform” in 1984 allowed for greater variation in pay across and within establishments (Zhang et al., 2005).

After 1990, Ministry of Labor started piloting a new job-based pay system in selected state enterprises. It conducted a job evaluation exercise and then paid employees a base salary according to the position they hold.2 The base pay also reflects the market value of the job. As cash compensation became more market-based, the government relieved enterprises from providing housing, medical service, and pension benefits to their employees. Housing was privatized, and the government established social funds of pension, health, and unemployment insurance. In these reforms the state differentiated among workers who retired before 1997, those who started work before 1997 and were still working then and those who started after 1997 in ways that meant that the reforms had a smaller impact on the older cohorts than on younger cohorts. For example, the older cohorts receive housing subsidy if their firm did not provide them apartments, while newer cohorts are not entitled to such benefits. This policy is described as "New People new rule, old people old rule".

In the mid and late 1990s state enterprises laid off millions of workers, which raised joblessness among urban workers. By the mid 1990s the labor bureau no longer allocated college graduates to jobs; individuals could choose their own workplace (Wei et al., 1997). In the 2000s as employment shifted to town and country enterprises and eventually to private enterprises, the government enacted laws that made it easier for the All China Federation of Trade Unions (ACFTU) to organize workers and encouraged ACFTU unions to represent workers rather than being "transmission

2 Ministry of Labor, "Notice on the Relevant Issues Concerning Experiment of Job-Based Pay System" (Document No. 2 [1992]). http://www.chinaorg.cn/zcfg/zcfg/2007-12/19/content_5153002.htm. 
belts" for the state and party. The Contract Labor law, which took effect in 2008, required firms to give migrant workers written contracts and strengthened worker rights to obtain permanent jobs.

\section{Changes in Demand and Supply}

The incipient labor market faced huge shifts in demand and supply associated with China's transition to a more market-based economy. Demand for labor increased massively due to China's rapid post reform economic growth. From the late 1980s to 2009, the annual average GDP growth rate was $9.6 \%$ according to official government statistics, albeit with business cycle swings around the average growth rate (Gong and Lin, 2008; Gao, 2007; Imai, 1996). NBS's China Statistical Yearbooks show that GDP growth rates plunged to 4.1 and 3.8 percent in 1989 and 1990, reaching the lowest level since the reform, and experienced another slow-down in 1998-1999. China expanded steadily from 2000 to 2008-2009 when the global financial crisis broke out. Part of China's increased demand for labor stemmed from exports. From 1989 to 2000 exports increased at an annual average rate of $16 \%$. After China joined the WTO in 2001, the annual export growth rate increased to over $20 \%$. Rapid export growth raised the demand for labor, especially low-skilled manufacturing workers. Another driver of China's economic growth was domestic fixed capital investment (FCI). The ratio of FCI to GDP increased from $27 \%$ to $65 \%$ during $1989-2009$.

The result of the strong economic growth was that employment increased from 520 million in the late 1980 s to 740 million in 2009.

On the supply side, China's population of working age persons has varied with the size of birth cohorts. The size of birth cohorts declined during the Great Famine period 1958-1961, then increased in the baby boom in the 1960s. There was another birth bust in the late 1970s as the Great Famine cohort entered reproductive age, followed by a mild baby boom in the early 1980s. The demographic cycle produced a large increase in supply in the 1980s when the post-famine baby boomers entered the labor force. Investments in education boosted the supply of skilled workers massively in the 1990s and 
2000s. The number of persons graduating college annually increased 570,000 in 1989 to about 6 million in 2009. Enrollments in high school increased from 2.4 million in the late 1980 s to 8.2 million in 2009.

Since the major labor market reforms in wage determination took place from the 1990s through the 2000s (Zhang et al., 2005; Appleton et al. 2005; Knight and Song, 2003), the Urban Household files provide evidence on the way in which the incipient labor market determined wages and employment in a period of huge economic change.

\section{Education, Experience, and Cohort Earnings Differentials}

Figures 1 and 2 display earnings differentials by education and experience from 1989 through 2008. Figure 1 shows that differentials in earnings between educational groups were small at the outset of the period and decreased from 1989 to 1991 but then increased after 1992. Figure 2 shows that experience pay differentials were relatively high at outset, decreased in the 1990s, bottomed out in 1999, then increased after 2000.

Since the data in both figures are averages unadjusted for other attributes of workers, they will be affected by changes in workers' characteristics over time and across the groups. To see whether the pattern of differentials in the figures hold up in the presence of other characteristics of workers, we estimated earnings differentials for education and years of experience from regressions that included measures of other characteristics (see regressions in Appendix A). The pattern of earnings coefficients for education and experience over time resemble those in figures 1 and 2. Together, figures 1 and 2 and the Appendix regressions suggest that young and skilled workers benefited most from the transformation of labor market in the early 1990s, but that increased supplies of young educated workers narrowed the educational differential while widening the experience differential.

In developed countries the wages and employment of younger workers vary more with economic conditions than do those of older workers. Cohorts that begin their work lives during a 
recession obtain lower earnings than cohorts that begin their work lives during boom years. Studies have also found that the earnings differentials due to the temporary conditions of the time of entry into the job market tend to persist for much of the work life (Rauum and Røed, 2006; Oreopoulos et al., 2006; Kahn, 2006; Oyer, 2006; Baker et al., 1994; Beaudry and DiNardo,1991; Freeman,1981.) To see whether cohort starting earnings vary substantially in China and whether cohort effects persist over time, we tabulated the log earning for workers who just left school to begin work and the earnings of the same cohorts three and five years later.

Column 1 of table 1 records the annual earnings of graduates who started work in each year from 1989 to 2009. Since graduation takes place in June, the earnings cover at most one half a year. Graduates who did not find work within six months of graduation are not included in the sample. Column 2 records the annual earnings of that same cohort in the first full year after leaving school. The table also records earnings of that cohort with 3 and 5 years of experience in the job market. For example, the 1989 figures in column 1 give earnings in the first half year of work life for graduates in that year, the earnings in column 2 give earnings for the same group in 1990, while the earnings in column 3 give that cohort's earnings in 1992 and the earnings in column 4 give cohort earnings in 1994. By inspection starting earnings are more volatile than earnings in the first year, which are more volatile than earnings in the third and fifth year. Formally, the standard deviation of the annual growth of earnings in 1989 to 2004, when we have earnings for all of the relevant groups are: 0.125 (starting); 0.081 (first year); 0.078 (third year); 0.078 (fifth year). As in other countries the earnings of new entrants in China varies more over time than the earnings of the same cohort later in its working life.

Columns 5 to 8 of table 1 record the difference in mean earnings of workers at their first postschooling job and three or five years later. Although the Urban Household Survey does not have longitudinal data for individuals, we can infer the longitudinal wage growth for a cohort from the cross section data. The difference in pay between persons of age $n$ in year 0 and age $n+t t$ years in the future 
is an unbiased estimate of change in earnings for the cohort. This is because the survey is a random sample in both periods.

To see whether a cohort that starts with relatively low earnings due to a bad labor market when they first enter the job market catches up with other cohorts or falls further behind, and conversely whether a cohort that starts with relatively high earnings due to a good labor market loses its advantage over time we regressed the changes in earnings in columns (5)-(8) on an estimate of whether the starting salary reflected a good or bad initial market. The estimated market condition was the residual from a regression of $1 n$ starting salary on a time trend. Panel A of table 2 records the regression coefficients and standard errors for the relation between cohort growth and the residual of the cohort's starting growth. The results show substantial "regression to the mean" in the form of sizable negative coefficients on starting or first year earnings. If the starting salary was lower in a year by $10 \%$ from the predicted trend, the growth rate in the first 3-5 years would be 12-14\% percent higher than it otherwise would have been, implying an approximately 3 year catch up period. This is a much faster catch-up than is found in the US and other advanced countries.

\section{Dispersion of Pay}

Figure 3 displays two measures of wage inequality: the variance of $\ln$ earnings and the ratio of the earnings of workers in the $75^{\text {th }}$ percentile to the earnings of those in the 25 th percentile of the earnings distribution for all workers and for those with specified levels of experience. Both measures show a huge increase in dispersion from relatively low levels at the outset to high levels at the end of the period, albeit with variation over time. Consider, for example, the pattern of change in the variance of ln earnings. The variance more than triples from 0.20 in 1989 to peak at about 0.65 in 2008 and then falls to 0.55 in 2009 . Within each experience group, moreover, both the variance and the quantile measure of inequality increase substantially, especially during the 1990s. And dispersion increased more for the older groups of workers than for the younger group of workers. This is different from the 
pattern of increase in wage dispersion in the US, where dispersion increased more for younger workers than for older workers (Autor et al., 2008; 2005). A likely reason for the greater increase in dispersion among the older workers is that their pay was still compressed from the pre-reform labor market, creating exceptionally low dispersion at the beginning of our period.

\section{Quantitative Adjustments}

Labor markets do not rely exclusively on price adjustments to deal with shifts in demand and supply. They also respond through quantitative adjustments in the form of changes in hours worked, unemployment, conditions of work, and so on. The Urban Household Survey does not identify workers without of jobs who actively search for work, so we cannot measure the impact of the changing market conditions on the standard rate of unemployment. Instead we focus on the employment rate - the ratio of persons in a given group employed - and on the quality of jobs that the employed obtain -- measured as the proportion of the group who work in jobs that would seem to fit more educated workers managerial, professional, technical and clerical jobs. The Urban Household Survey does not have more detailed information on occupations for a more refined measure of the jobs.

Figure 4 shows that the employment rate fell during the reform period, particularly in the mid to late 1990s as SOEs displaced workers and again in the early 2000s and late 2000s when economic growth slowed. The figure also shows the near universal pattern in which the less experienced group of workers had lower employment rates than more experienced workers.

Figure 5 looks at the quality of jobs that the employed get, in terms of the proportion of workers in a white collar occupation for workers with different years of schooling. College graduates experienced a decline in the good occupation rate while high school and junior high graduates had a slight increase in the rate. Before the reform, the government assigned college graduates to white collar jobs. Post 2000 the huge increase in the supply of college graduates increased the supply of graduates so much that market demand was not enough to employ the same proportion in those areas as 
in the past. This is a normal labor market response to huge increases in the supply of graduates.

Figure 6 shows that the proportion of workers who obtain white collar jobs in a cohort rises with experience. The line for starting workers is the lowest in most years while the line for workers with five or more years experience is the highest in almost every year. The proportion of the workers starting in good jobs varies substantially more over time than the proportion of more experienced workers in good jobs. 3 The figure also shows that the gap between the two groups widened in recent years.

To see whether workers who started in a less desirable job recovered over time (as occurred with earnings) we regressed the change in the proportion of workers in a good job of a cohort on the estimated "excess" proportion of that cohort who started in a good occupation - the deviation of the proportion from a time trend. The estimates in panel B of table 2 for starting jobs and jobs in the first year after leaving school show negative coefficients on the starting or first year job similar to the negative coefficients in earnings in panel A of the table. The results suggest that if the starting occupation was lower in a year by $10 \%$, the growth rate in the first $3-5$ years would be $7-17 \%$ percent higher, and it would take approximately 3-4 years to catch up in terms of occupational attainment. Again, the effect of entering in a weak or strong labor market decays fairly quickly.

\section{Estimated Demand and Supply Effects from Provincial Data}

Our analysis has shown what happened over time, but twenty-one years of time series data is inadequate to estimate the impacts of shifts in demand and supply on the structure of wages or measures of quantitative adjustment. Accordingly, we developed a pooled time series cross province data set from the Urban Household Survey We calculated mean earnings, dispersion of earnings, and the quantitative measures of labor outcomes for workers entering the labor market at different years for

3 To see whether the pattern of occupation status is affected by personal characteristics, we run regressions of starting, 1st, 3rd, and 5th year occupation on entry year dummies and measures of individual's personal characteristics. The regression results are in the Appendix B. The results show similar differences by experience and time to those in the figures. 
each province. We also estimated the size of cohorts and the average education, and experience level of workers by entry year for each province. We merged these data with China Statistical Yearbook measures of GDP, exports, and fixed capital investment at the province level. We then estimated the relation between a measure of the supply of workers -- the ln number of persons in a cohort in a province-- and a measure of demand -- ln GDP in the province -- on labor market outcomes for cohorts with different levels of experience.

Table 3 reports the results of this analysis for three groups of workers: workers in the first year of their career after leaving school; workers with three years of experience; and workers with five years of experience. Since provinces differ substantially in their economic development, the regressions under the title "models with province dummies" include dummies for each of the provinces. Since provinces may also differ in the speed of reforms and adjustments, the regressions under the title "models with dummy variables and province trends" also include independent trend terms for each province.

There are three findings in the table. First, the coefficients on the cohort size variable and on entry year GDP are much greater and statistically significant for the workers in their first year than for those with three or five years experience. Cohort size has a sizable negative impact on mean $\ln$ earnings, standard deviation of ln earnings, and the log of the quartile differences in earnings regardless of the model for the workers beginning their careers compared to much weaker effects for the other groups. Being in a large cohort depresses starting wages and increases the dispersion of pay for the group but the cohort size effects largely disappear for the older groups. Second, the coefficients on the entry year ln GDP variable are weaker in the models that include province trends than in those that do not. Absent province trends, entry year GDP has a significant impact in every calculation for all of the groups. Higher province level GDP raises earnings, raises dispersion of pay and raises the employment rate and the proportion of workers in white collar jobs, as shift in demand for labor should 
do. Addition of the province trends reduces the significance of the estimated coefficients in all the calculations and essentially eliminates the effect of entry year GDP for workers with five years of work experience. Third, the calculations show that cohort size and entry year GDP have weaker and less consistent effects on the employment rate and percentage of workers in white collar jobs than o the wage variables. The estimated effects for cohort size are significant only on the employment rate for workers in the first year of their career while the estimated effects for entry year level GDP are strong for several groups.

In sum, the province level data in table 3 supports the notion that changes in supply and demand impact starting workers more than others and that cohort effects are short-run only. We interpret the positive coefficients on the size of cohort and on ln GDP on the measures of dispersion as reflecting similar phenomenon: an increase in the number of workers spreads workers over a larger number of firms with differing wages; while an increase in GDP increases in the number of places hiring workers, which also spreads workers over jobs with differing wages.

Finally, we estimated the impact of changes in demand as a cohort gains experience on changes in earnings conditional on the initial earnings of the cohort. The dependent variable in these regressions is the change in mean earnings for a cohort from year 1 to year 3 from year 1 to year 5 by province and year. The independent variables are the growth of GDP and the ln earnings of the cohort in year 1 . The estimated coefficients on the demand side variables show the sensitivity of longitudinal earnings patterns to changes in demand as a cohort ages. The estimated coefficients on the ln earnings in the first year provide another test of the "catch up effect" in longitudinal earnings growth, in this case conditional on the increase in demand. The estimates provide strong support for both the effect of demand factors and for catch-up. Workers with lower starting earnings had a greater earnings growth from year 1 to 3,3 to 5 , and 1 to 5 . Stronger economic growth coincided with the greater earnings growth. 


\section{Conclusion}

China's emerging labor market was buffeted by huge changes in demand, and supply in the 1990s and 2000s. Our analysis shows that the market responded with substantial changes in the structure of wages and in employment and types of jobs held that largely mirror the adjustments found in labor markets in advanced countries. Using province level data over time, we find that wages, dispersion of wages, employment rates and the percent of workers who obtain white collar jobs are substantially affected by supply as measured by cohort size and demand forces, as measured by GDP.

The one place where the Chinese labor market appears to diverge from labor markets in advanced countries is the rapid convergence in earnings and occupational position of cohorts who entered the job market under more or less favorable conditions. On this dimension China's labor market seems more flexible than those in other countries. Three related factors may explain this pattern: 1) the rapid growth of the Chinese economy, which may overwhelm short term fluctuations in the fortunes of particular cohorts ; 2) the high rate of turnover in China, where prior to 2008 average turnover rate was over $15 \%$ and reached $30 \%$ in some sectors, that would create great opportunities for people to recover or to lose; and 3) the relative weakness of internal labor markets in China, in which firms place employees through less formal hiring systems and modes of wage setting than in firms in more developed economies.

Bottom line, the Chinese labor market has responded about as well as one could expect to the huge changes in supply and demand that impacted it in the period under study. 
Table 1: Starting earnings, earnings in the 1st, 3rd, and 5th year, and earnings growth

\begin{tabular}{|c|c|c|c|c|c|c|c|c|}
\hline & \multicolumn{4}{|c|}{$\underline{\text { Log earnings }}$} & \multicolumn{4}{|c|}{ Log earnings growth } \\
\hline & $\begin{array}{c}\text { Starting } \\
\text { (1) }\end{array}$ & $\begin{array}{c}\text { 1st year } \\
\text { (2) }\end{array}$ & $\begin{array}{c}\text { 3rd year } \\
\text { (3) }\end{array}$ & $\begin{array}{c}5 \text { th year } \\
\text { (4) }\end{array}$ & $\begin{array}{l}\text { Starting- } \\
\text { 3rd year } \\
(5)=(3)-(1)\end{array}$ & $\begin{array}{l}\text { Starting- } \\
\text { 5th year } \\
(6)=(4)- \\
(1)\end{array}$ & $\begin{array}{c}1 \text { st - } \\
\text { 3rd year } \\
(7)=(3)-(2)\end{array}$ & $\begin{array}{c}1 \text { st - } \\
5 \text { th year } \\
(8)=(4)-(2)\end{array}$ \\
\hline 1989 & 5.670 & 6.360 & 6.906 & 7.172 & 1.236 & 1.502 & 0.546 & 0.812 \\
\hline 1990 & 5.663 & 6.450 & 7.001 & 7.147 & 1.338 & 1.484 & 0.551 & 0.697 \\
\hline 1991 & 5.906 & 6.741 & 6.991 & 7.145 & 1.085 & 1.239 & 0.25 & 0.404 \\
\hline 1992 & 6.114 & 6.893 & 7.139 & 7.192 & 1.025 & 1.078 & 0.246 & 0.299 \\
\hline 1993 & 6.292 & 6.936 & 7.181 & 7.319 & 0.889 & 1.027 & 0.245 & 0.383 \\
\hline 1994 & 6.192 & 7.016 & 7.114 & 7.455 & 0.922 & 1.263 & 0.098 & 0.439 \\
\hline 1995 & 6.381 & 7.051 & 7.224 & 7.465 & 0.843 & 1.084 & 0.173 & 0.414 \\
\hline 1996 & 6.531 & 7.117 & 7.352 & 7.581 & 0.821 & 1.05 & 0.235 & 0.464 \\
\hline 1997 & 6.568 & 7.202 & 7.573 & 7.757 & 1.005 & 1.189 & 0.371 & 0.555 \\
\hline 1998 & 6.538 & 7.383 & 7.547 & 7.701 & 1.009 & 1.163 & 0.164 & 0.318 \\
\hline 1999 & 6.724 & 7.360 & 7.535 & 7.825 & 0.811 & 1.101 & 0.175 & 0.465 \\
\hline 2000 & 6.672 & 7.428 & 7.626 & 8.002 & 0.954 & 1.33 & 0.198 & 0.574 \\
\hline 2001 & 6.866 & 7.416 & 7.774 & 8.111 & 0.908 & 1.245 & 0.358 & 0.695 \\
\hline 2002 & 6.704 & 7.474 & 7.923 & 8.223 & 1.219 & 1.519 & 0.449 & 0.749 \\
\hline 2003 & 6.841 & 7.652 & 8.014 & 8.375 & 1.173 & 1.534 & 0.362 & 0.723 \\
\hline 2004 & 7.061 & 7.685 & 8.112 & 8.569 & 1.051 & 1.508 & 0.427 & 0.884 \\
\hline 2005 & 7.044 & 7.845 & 8.264 & & & & & \\
\hline 2006 & 7.265 & 8.022 & 8.421 & & & & & \\
\hline 2007 & 7.437 & 8.055 & & & & & & \\
\hline 2008 & 7.401 & 8.242 & & & & & & \\
\hline 2009 & 7.491 & & & & & & & \\
\hline
\end{tabular}

Source: NBS urban household survey data; author's calculation 
Table 2: Regressions of Change in Cohort Earnings or Occupational Position on Cohort Starting Position

Panel A: the dependent variable is growth in ln Earnings

\begin{tabular}{|c|c|c|c|c|c|}
\hline & $\begin{array}{c}\text { ln Earnings } \\
\text { 3rd } \\
\text { year/starting }\end{array}$ & $\begin{array}{l}\text { In Earnings } \\
5 \text { th } \\
\text { year/starting }\end{array}$ & $\begin{array}{l}\text { Ln earnings } \\
\text { 3rd year/1st }\end{array}$ & & $\begin{array}{l}\text { Ln earnings } \\
5 \text { th year/ } 1^{\text {st }}\end{array}$ \\
\hline Starting earnings & $\begin{array}{c}-0.012 * * * \\
(0.002)\end{array}$ & $\begin{array}{c}-0.014 * * * \\
(0.002)\end{array}$ & & & \\
\hline 1st year earnings & & & $\begin{array}{c}-0.012 * * * \\
(0.002)\end{array}$ & $\begin{array}{c}-0.011 * * * \\
(0.002)\end{array}$ & $\begin{array}{c}-0.018 * * * \\
(0.002)\end{array}$ \\
\hline $\begin{array}{l}\text { 1st year earnings } \\
\text { squared }\end{array}$ & & & & $\begin{array}{c}0.0006^{* *} \\
(0.0003)\end{array}$ & \\
\hline Constant & $\begin{array}{c}1.024 * * * \\
(0.021)\end{array}$ & $\begin{array}{c}1.277 * * * \\
(0.023)\end{array}$ & $\begin{array}{c}0.296 * * * \\
(0.021)\end{array}$ & $\begin{array}{c}0.243 * * * \\
(0.027)\end{array}$ & $\begin{array}{c}0.544 * * * \\
(0.017)\end{array}$ \\
\hline $\begin{array}{l}\text { Number of obs. } \\
\text { Adj. } R^{2}\end{array}$ & $\begin{array}{c}16 \\
0.721\end{array}$ & $\begin{array}{c}16 \\
0.765\end{array}$ & $\begin{array}{c}16 \\
0.644\end{array}$ & $\begin{array}{c}16 \\
0.744\end{array}$ & $\begin{array}{c}16 \\
0.862\end{array}$ \\
\hline
\end{tabular}

Panel B: the dependent variable is the change in proportion of workers in managerial, professional, technical and clerical jobs

\begin{tabular}{lccccc}
\hline & $\begin{array}{c}\text { 3rd year- } \\
\text { starting }\end{array}$ & $\begin{array}{c}\text { 5th year- } \\
\text { starting }\end{array}$ & 3rd year- 1st & 5th year - 1st \\
\hline Starting & $-0.010^{* * *}$ & $-0.013^{* * *}$ & & & \\
occupation & $(0.002)$ & $(0.002)$ & $-0.007 * * *$ & - & $-0.013 * * *$ \\
1st year & & $(0.002)$ & $0.006 * * *$ & $(0.002)$ \\
occupation & & & $(0.002)$ & \\
& & & $0.0006^{*}$ & \\
1st year & & & $(0.0003)$ & \\
occupation ${ }^{2} 2$ & $0.053^{* * *}$ & $0.053^{* * *}$ & $0.041 * * *$ & $0.029 * * *$ & $0.103 * * *$ \\
Constant & $(0.010)$ & $(0.010)$ & $(0.009)$ & $(0.011)$ & $(0.008)$ \\
& 16 & 16 & 16 & 16 & 16 \\
Number of obs. & 0.751 & 0.751 & 0.445 & 0.523 & 0.776 \\
Adj. $\mathrm{R}^{2}$ & & & & & \\
\hline
\end{tabular}

Source: NBS urban household survey data; author's calculation

Note: In Panel A, starting or $1^{\text {st }}$ year earnings are relative earnings, indicating to what extent the earnings exceed the time trend, equal to the gap between actual starting/1st year earnings and the predicted ones from time trend, in percent. In Panel B, starting or 1st year occupation is the percentage of employees starting in good occupation in excess of time trend, equal to actual percentage minus the predicted value in percent.

$*, * *, * * *$ indicate statistical significance at the 10,5 , and $1 \%$ level. 
Table 3: Regression Coefficients linking Labor Outcomes to cohort size and entry year GDP, pooled Province by Year data set, 1988-2008

Models with province dummies $\quad$ Models with province dummies and province trends

\begin{tabular}{|c|c|c|c|c|c|c|}
\hline & $\begin{array}{l}\text { Cohort } \\
\text { Size }\end{array}$ & $\begin{array}{l}\text { Entry yr } \\
\text { Ln GDP }\end{array}$ & $\begin{array}{l}\text { Adj. } \\
\mathrm{R}^{2}\end{array}$ & Cohort Size & $\begin{array}{l}\text { Entry yr } \\
\text { Ln GDP }\end{array}$ & $\begin{array}{l}\text { Adj. } \\
\mathrm{R}^{2}\end{array}$ \\
\hline \multicolumn{7}{|l|}{ First year at work } \\
\hline Mean ln earnings & $-0.762 * *$ & $0.824 * * *$ & 0.886 & $-0.908 * * *$ & $0.548 * * *$ & 0.903 \\
\hline Std deviation of ln earnings & $1.426 * * *$ & $0.040 * * *$ & 0.109 & $1.509 * * *$ & 0.047 & 0.134 \\
\hline $\begin{array}{l}\text { Log (earnings in } 75^{\text {th }} \mathrm{q} \text {-tile/ } \\
\text { earnings in } 25^{\text {th }} \mathrm{q} \text {-tile) }\end{array}$ & $0.786^{* *}$ & $0.042 * * *$ & 0.063 & $0.900 * * *$ & $0.097^{*}$ & 0.090 \\
\hline Employment rate & $-0.102 *$ & $0.013 * * *$ & 0.219 & $-0.115^{* *}$ & $0.020 * * *$ & 0.273 \\
\hline$\%$ in white collar jobs & -0.103 & $0.057 * * *$ & 0.286 & -0.035 & 0.009 & 0.336 \\
\hline
\end{tabular}

Three years work experience

$\begin{array}{lllllll}\text { Mean ln earnings } & -0.573 * * & 0.740 * * * & 0.853 & -0.443 * * & 0.276 * * * & 0.890 \\ \text { Std deviation of ln earnings } & 0.433 * * & 0.061 * * * & 0.146 & 0.473 * * * & 0.053 & 0.195 \\ \begin{array}{l}\text { Log (earnings in } 75^{\text {th }} \text { q-tile/ } \\ \text { earnings in 25 }\end{array} & 0.819 * * * & 0.084 * * * & 0.131 & 0.877 * * * & 0.082 & 0.145 \\ \begin{array}{l}\text { Employment rate } \\ \text { \% in white collar jobs }\end{array} & -0.021 & 0.010 * * * & 0.082 & -0.045 & 0.016 * * & 0.135 \\ & -0.015 & 0.063 * * * & 0.299 & -0.050 & 0.029 & 0.342\end{array}$

Five years work experience

\begin{tabular}{|c|c|c|c|c|c|c|}
\hline Mean ln earnings & -0.223 & $0.653 * * *$ & 0.809 & -0.253 & 0.071 & 0.874 \\
\hline Std deviation of ln earnings & 0.279 & $0.056 * * *$ & 0.188 & $0.386 *$ & 0.002 & 0.195 \\
\hline $\begin{array}{l}\text { Log (earnings in } 75^{\text {th }} \mathrm{q} \text {-tile/ } \\
\text { earnings in } 25^{\text {th }} \mathrm{q} \text {-tile) }\end{array}$ & 0.012 & $0.093 * * *$ & 0.173 & 0.223 & 0.079 & 0.212 \\
\hline Employment rate & -0.005 & 0.003 & 0.073 & -0.002 & 0.003 & 0.073 \\
\hline$\%$ in white collar jobs & -0.067 & $0.066 * * *$ & 0.261 & -0.165 & 0.006 & 0.322 \\
\hline
\end{tabular}

Note: NBS urban household survey data; China Statistical yearbooks; There are total 31 provinces excluding Taiwan, Hong Kong, and Macao. Chongqin municipal reported statistics separately from Sichuan province since 1996. To keep consistency, we merge Chongqin data back into Sichuan province. This gives 30 observations per year for 21 years, for 630 observations.. $*, * *, * * *$ indicate statistical significance at the 10,5 , and $1 \%$ level. 
Table 4: Demand and supply, starting earnings, and earnings growth

\begin{tabular}{|c|c|c|c|}
\hline & Earnings growth & \multicolumn{2}{|c|}{ Earnings growth year3- } \\
\hline & year1-3 & 5 & 5 \\
\hline Log starting earnings & $-0.240 * * *$ & $-0.212 * * *$ & $-0.388 * * *$ \\
\hline GDP growth year1-3 & $0.342 * * *$ & & \\
\hline GDP growth year3-5 & & 0.078 & \\
\hline GDP growth year1-5 & & & $0.155 * * *$ \\
\hline constant & $2.212 * * *$ & $1.945 * * *$ & $3.676^{* * *}$ \\
\hline Number of obs. & 600 & 540 & 540 \\
\hline Adj. $R^{2}$ & 0.243 & 0.151 & 0.395 \\
\hline
\end{tabular}

Source: NBS urban household survey data; China Statistical yearbooks

Note: There are total 31 provinces excluding Taiwan, Hong Kong, and Macao. Chongqin municipal reported statistics separately from Sichuan province since 1996. To keep consistency, we merge Chongqin data back into Sichuan province. Thus there are 30 observations per year for 20 years (19882007) for year1-3 earnings growth regressions, and 18 years (1988-2005) for year1-5 and 3-5 growth regression.

$*, * *, * * *$ indicate statistical significance at the 10,5 , and $1 \%$ level. 


\section{Figure 1: Skill differences in mean earnings}

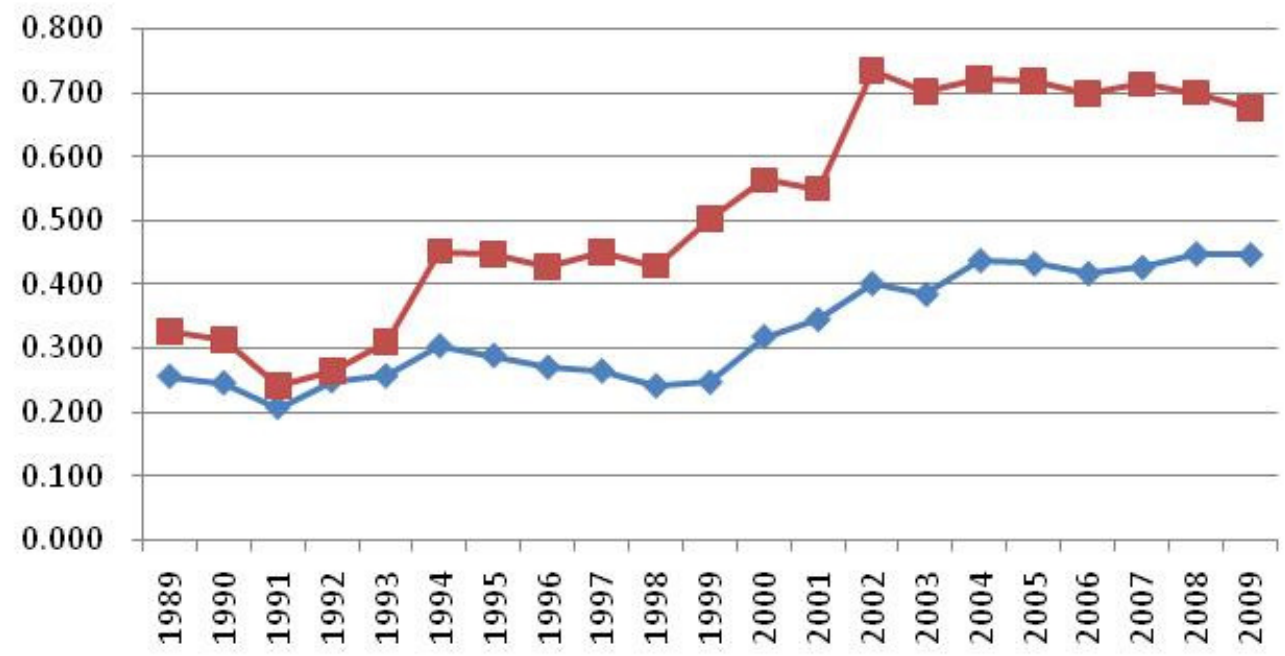

$\multimap$ difference in earnings between college and high school graduates

$\rightarrow$-difference in earnings between college and junior high and below education

Source: NBS urban household survey data, author's calculation

Figure 2: Gap in In mean earnings between those with 1-3 years of experience and those with more years of experience. 1989-2009

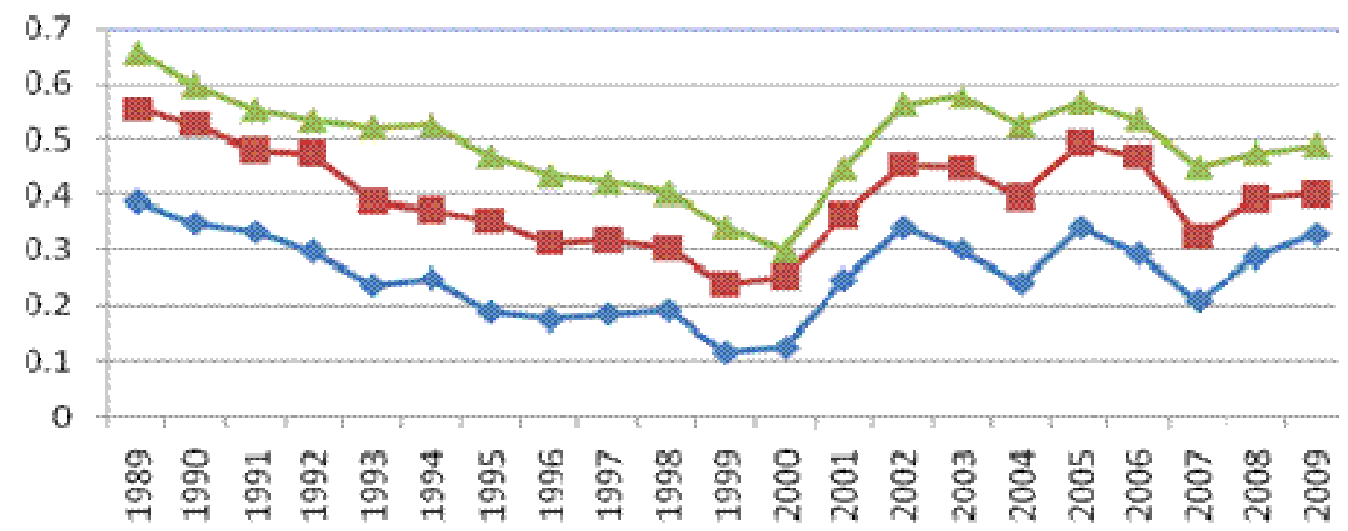

$\Rightarrow$ - difference in earnings between 4-6 and 1-3 years of experiences

-min-m difference in eamings between $7-9$ and $1+3$ years of experiences

7 - difference in earnings between $11-12$ and $1-3$ years of experiences

\section{Source: NBS urban household survey data, author's calculation}


Figure 3a: Variances of In earnings by experience group

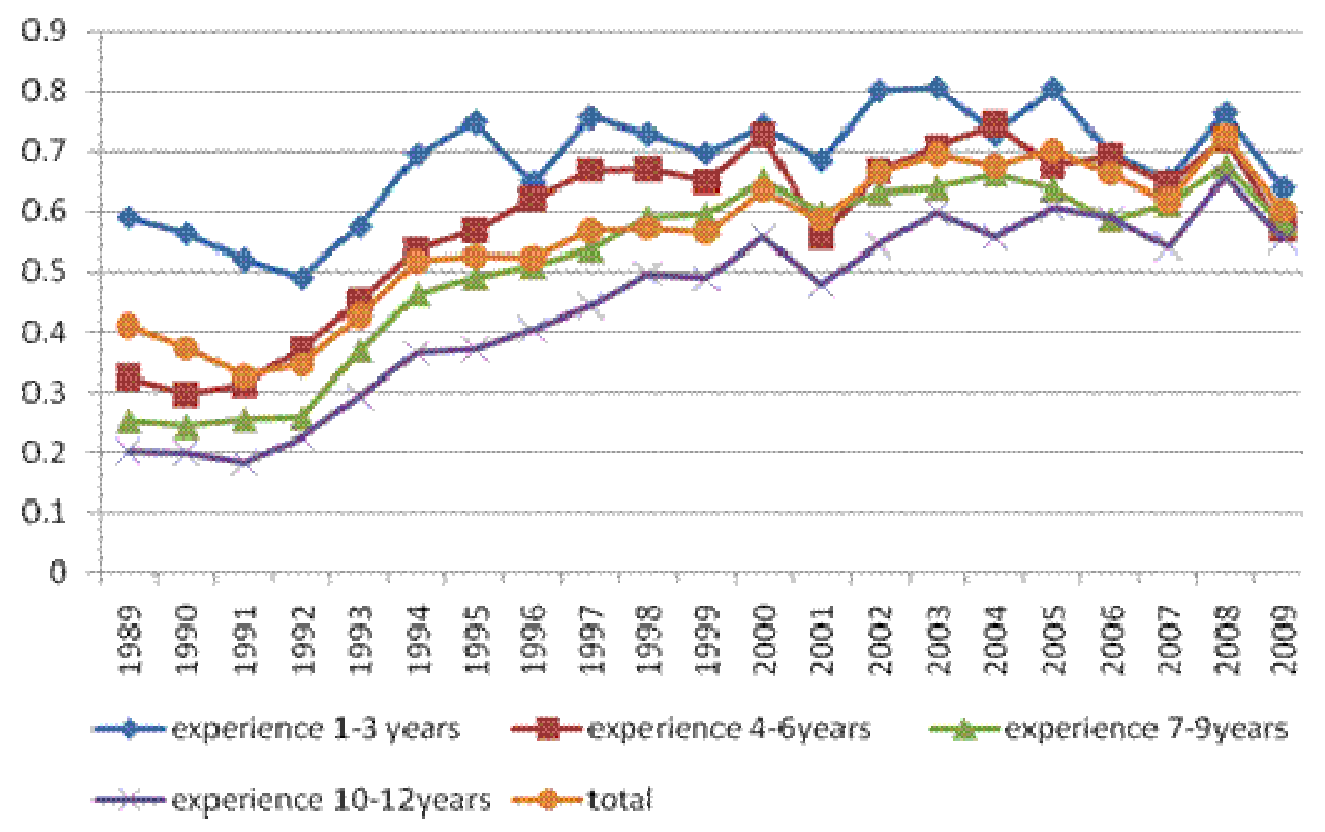

Figure 3b: Ratio of earnings at 75 th percentile to 25 th percentile by experience groups

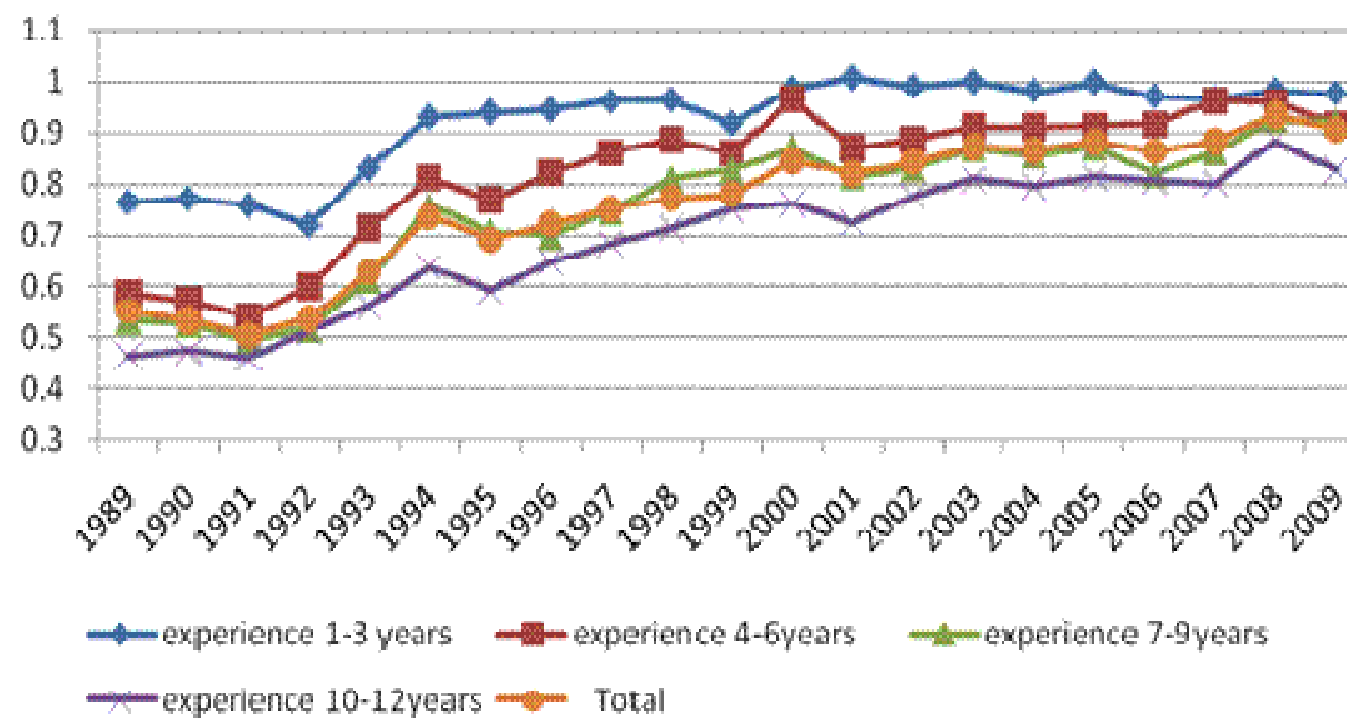

Source: NBS urban household survey data, author's calculation 
Figure 4: Employment rates by experience group, by survey year

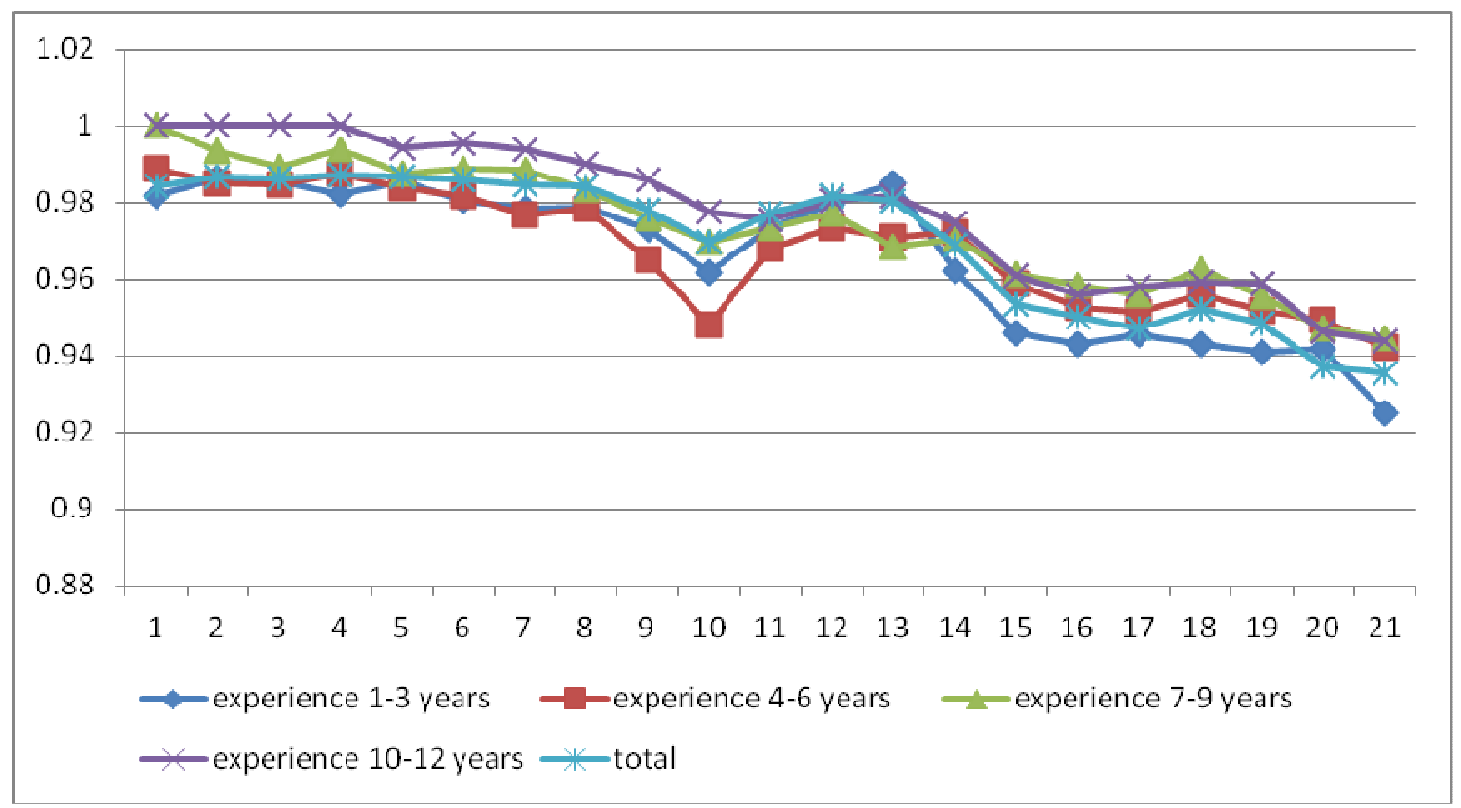

Source: NBS urban household survey data, author's calculation

Figure 5: Proportion of workers starting in managerial, professional, technical, or clerical jobs, 1989-2009

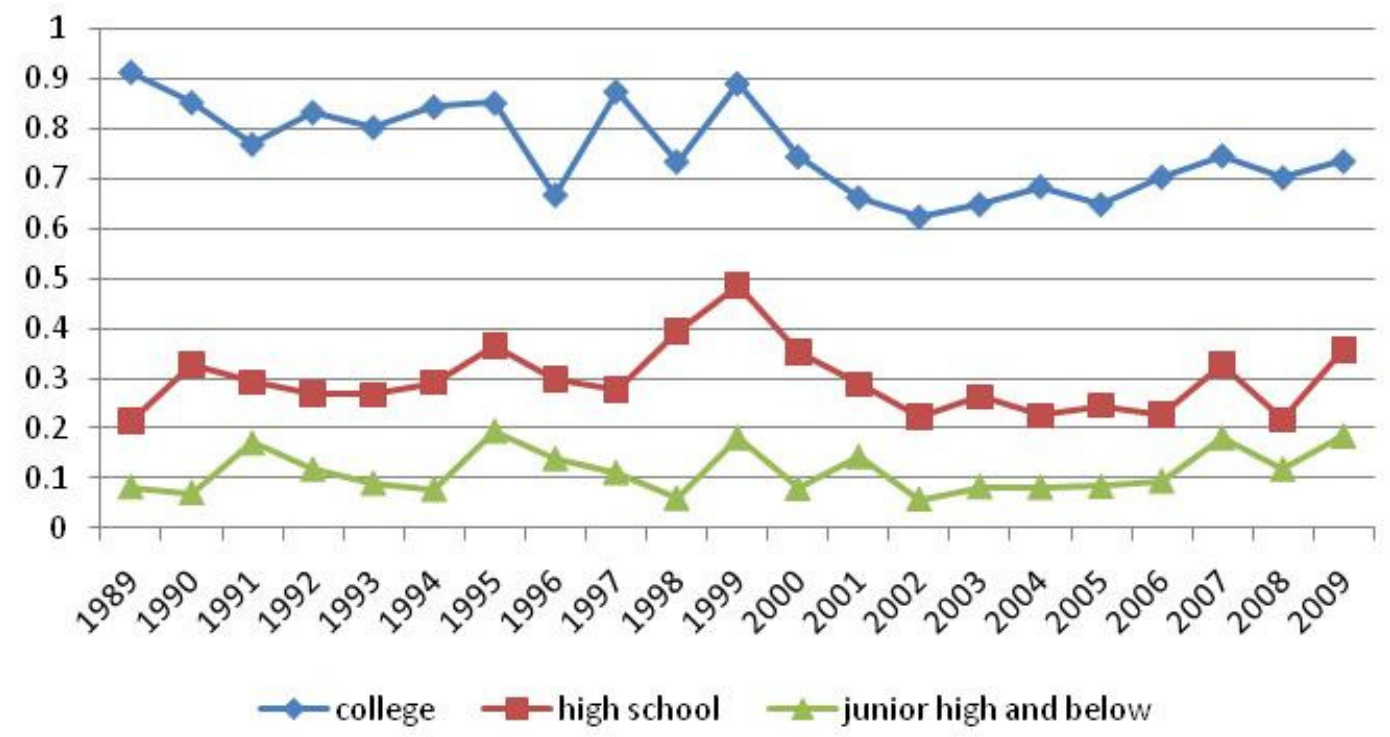

Source: NBS urban household survey data; author's calculation 
Figure 6: Proportion of workers in given cohorts in managerial, professional, technical, or clerical jobs,

1989-2009

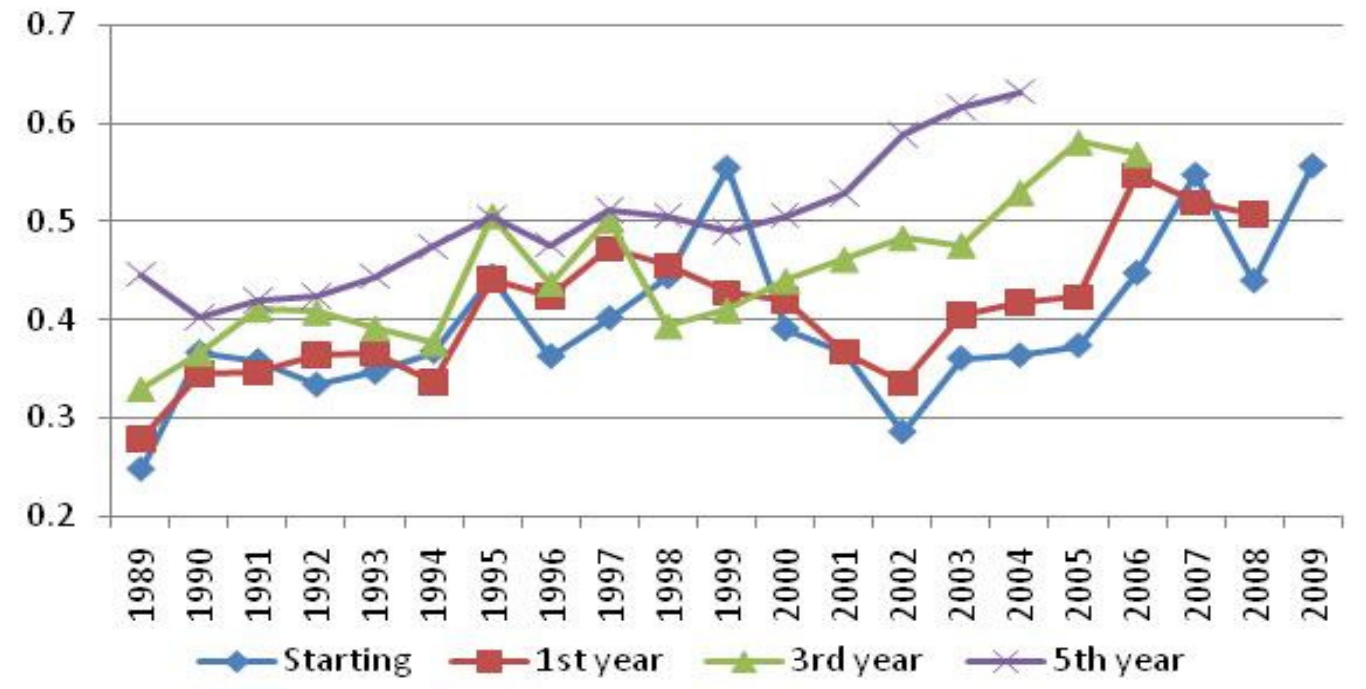

Source: NBS urban household survey data; author's calculation 
Appendix A: Entry year effect of earnings with control variables

\begin{tabular}{|c|c|c|c|c|}
\hline Entry year & $\begin{array}{l}\text { Log starting } \\
\text { earnings }\end{array}$ & $\begin{array}{l}\log 1^{\text {st }} \text { year } \\
\text { earnings }\end{array}$ & $\begin{array}{l}\log 3^{\text {rd }} \text { year } \\
\text { earnings }\end{array}$ & $\begin{array}{l}\text { Log } 5 \text { th year } \\
\text { earnings }\end{array}$ \\
\hline 1984 & & & & $-0.374 * * *$ \\
\hline 1985 & & & & $-0.271 * * *$ \\
\hline 1986 & & & $-0.190 * * *$ & $-0.196 * * *$ \\
\hline 1987 & & & $-0.167 * * *$ & $-0.104 * *$ \\
\hline 1988 & & 0.058 & $-0.202 * * *$ & -0.049 \\
\hline 1989 & - & - & - & - \\
\hline 1990 & -0.021 & 0.071 & 0.054 & -0.018 \\
\hline 1991 & $0.228 * *$ & $0.414 * * *$ & 0.03 & -0.058 \\
\hline 1992 & $0.350 * * *$ & $0.524 * * *$ & $0.174 * * *$ & -0.002 \\
\hline 1993 & $0.565 * * *$ & $0.584 * * *$ & $0.196 * * *$ & $0.109 * *$ \\
\hline 1994 & $0.455 * * *$ & $0.668 * * *$ & $0.181 * * *$ & $0.201 * * *$ \\
\hline 1995 & $0.645 * * *$ & $0.700 * * *$ & $0.232 * * *$ & $0.229 * * *$ \\
\hline 1996 & $0.802 * * *$ & $0.738 * * *$ & $0.339 * * *$ & $0.375 * * *$ \\
\hline 1997 & $0.843 * * *$ & $0.737 * * *$ & $0.534 * * *$ & $0.519 * * *$ \\
\hline 1998 & $0.805 * * *$ & $0.948 * * *$ & $0.642 * * *$ & $0.456 * * *$ \\
\hline 1999 & $0.972 * * *$ & $0.983 * * *$ & $0.570 * * *$ & $0.556 * * *$ \\
\hline 2000 & $0.972 * * *$ & $1.088 * * *$ & $0.620 * * *$ & $0.710 * * *$ \\
\hline 2001 & $1.163 * * *$ & $1.076 * * *$ & $0.766 * * *$ & $0.778 * * *$ \\
\hline 2002 & $0.973 * * *$ & $1.108 * * *$ & $0.868 * * *$ & $0.852 * * *$ \\
\hline 2003 & $1.089 * * *$ & $1.269 * * *$ & $0.967 * * *$ & $0.966 * * *$ \\
\hline 2004 & $1.287 * * *$ & $1.287 * * *$ & $1.024 * * *$ & $1.127 * * *$ \\
\hline 2005 & $1.268 * * *$ & $1.424 * * *$ & $1.135 * * *$ & \\
\hline 2006 & $1.445 * * *$ & $1.511 * * *$ & $1.300 * * *$ & \\
\hline 2007 & $1.590 * * *$ & $1.603 * * *$ & & \\
\hline 2008 & $1.592 * * *$ & $1.736 * * *$ & & \\
\hline 2009 & $1.662 * * *$ & & & \\
\hline male & $0.045^{*}$ & $0.067 * * *$ & $0.115 * * *$ & $0.115 * * *$ \\
\hline College grad. & $0.068 * *$ & $0.234 * * *$ & $0.242 * * *$ & $0.250 * * *$ \\
\hline Junior high \& below & $-0.088 * * *$ & $-0.145^{* * *}$ & $-0.175^{* * *}$ & $-0.135 * * *$ \\
\hline Privately owned & 0.022 & $-0.098 * * *$ & $-0.111 * * *$ & $-0.081 * * *$ \\
\hline Collectively owned & 0.009 & $-0.103 * * *$ & $-0.139 * * *$ & $-0.120 * * *$ \\
\hline Manufacturing & -0.05 & 0.008 & 0.034 & -0.033 \\
\hline Construction & -0.019 & -0.02 & 0.005 & -0.044 \\
\hline Transportation & 0.014 & 0.051 & $0.131 * * *$ & $0.080^{* *}$ \\
\hline Commerce & -0.047 & 0.012 & 0.017 & $-0.091 * * *$ \\
\hline Social service & -0.01 & -0.039 & -0.012 & $-0.074 * *$ \\
\hline Education, health, sports & $-0.142 * *$ & -0.027 & 0.004 & -0.04 \\
\hline Science & 0.013 & $0.086^{*}$ & $0.103 * *$ & -0.014 \\
\hline finance & 0.022 & 0.044 & $0.090 * *$ & 0.021 \\
\hline Other & -0.044 & 0.043 & $0.074 *$ & 0.033 \\
\hline Professional occ. & $0.127 * * *$ & $0.163 * * *$ & $0.180 * * *$ & $0.232 * * *$ \\
\hline Managerial occ. & $0.347 *$ & $0.166^{*}$ & 0.064 & $0.338 * * *$ \\
\hline Clerical & $0.125 * * *$ & $0.104 * * *$ & $0.112 * * *$ & $0.146 * * *$ \\
\hline Commercial \& service & -0.052 & $-0.089 * * *$ & $-0.115^{* * *}$ & $-0.084 * * *$ \\
\hline Province dummies & yes & yes & yes & yes \\
\hline Constant & $6.852 * * *$ & $6.458 * * *$ & $7.236 * * *$ & $7.510 * * *$ \\
\hline Number of obs. & 8788 & 17284 & 18877 & 17891 \\
\hline Adj. $R^{2}$ & 0.331 & 0.477 & 0.498 & 0.475 \\
\hline
\end{tabular}

Source: NBS urban household survey. $*, * *, * * *$ indicate statistical significance at 10,5 , and $1 \%$ level. 
Appendix B: Entry year effect on occupation with control variables

\begin{tabular}{|c|c|c|c|c|}
\hline & $\begin{array}{l}\text { Log starting } \\
\text { occupation }\end{array}$ & $\begin{array}{l}\text { Log } 1^{\text {st }} \text { year } \\
\text { occupation }\end{array}$ & $\begin{array}{l}\log 3^{\text {rd }} \text { year } \\
\text { occupation }\end{array}$ & $\begin{array}{l}\text { Log } 5 \text { th year } \\
\text { occupation }\end{array}$ \\
\hline \multicolumn{5}{|l|}{ Entry year } \\
\hline 1984 & & & & $-0.083 * * *$ \\
\hline 1985 & & & & $-0.054^{*}$ \\
\hline 1986 & & & $-0.072 * * *$ & -0.031 \\
\hline 1987 & & & -0.034 & -0.015 \\
\hline 1988 & & 0.026 & $-0.042 *$ & -0.037 \\
\hline 1989 & - & - & - & - \\
\hline 1990 & $0.078 *$ & 0.052 & 0.0003 & -0.015 \\
\hline 1991 & 0.051 & $0.056 *$ & 0.024 & -0.010 \\
\hline 1992 & 0.049 & $0.072 * *$ & 0.031 & -0.020 \\
\hline 1993 & 0.058 & $0.078 * *$ & 0.006 & -0.029 \\
\hline 1994 & 0.062 & 0.045 & -0.013 & -0.023 \\
\hline 1995 & $0.149 * * *$ & $0.114 * * *$ & 0.034 & 0.010 \\
\hline 1996 & 0.063 & $0.100 * * *$ & -0.0002 & 0.003 \\
\hline 1997 & $0.103 * *$ & $0.099 * * *$ & 0.011 & $0.039^{*}$ \\
\hline 1998 & $0.116 * * *$ & $0.092 * * *$ & -0.012 & $0.045^{*}$ \\
\hline 1999 & $0.213 * * *$ & $0.075 * *$ & 0.027 & -0.019 \\
\hline 2000 & $0.112 * *$ & $0.078 * *$ & 0.027 & 0.007 \\
\hline 2001 & $0.081 *$ & $0.091 * * *$ & 0.014 & -0.008 \\
\hline 2002 & $0.078 * *$ & $0.049 *$ & 0.011 & 0.031 \\
\hline 2003 & $0.117 * * *$ & $0.067 * *$ & 0.003 & $0.060 * * *$ \\
\hline 2004 & $0.093 * * *$ & $0.086 * * *$ & $0.043 *$ & $0.059 * *$ \\
\hline 2005 & $0.092 * * *$ & $0.069 * * *$ & $0.073 * * *$ & \\
\hline 2006 & $0.105 * * *$ & $0.131 * * *$ & $0.073 * * *$ & \\
\hline 2007 & $0.166 * * *$ & $0.134 * * *$ & & \\
\hline 2008 & $0.121 * * *$ & $0.107 * * *$ & & \\
\hline 2009 & $0.170 * * *$ & & & \\
\hline male & $-0.018 *$ & $-0.019 * *$ & $-0.015 * *$ & $-0.028 * * *$ \\
\hline College grad. & $0.334 * * *$ & $0.349 * * *$ & $0.334 * * *$ & $0.316 * * *$ \\
\hline Junior high \& below & $-0.119 * * *$ & $-0.134 * * *$ & $-0.152 * * *$ & $-0.195 * * *$ \\
\hline Privately owned & $-0.131 * * *$ & $-0.121 * * *$ & $-0.119 * * *$ & $-0.124 * * *$ \\
\hline Collectively owned & $-0.089 * * *$ & $-0.090 * * *$ & $-0.088 * * *$ & $-0.067 * * *$ \\
\hline Industry dummies & yes & yes & yes & yes \\
\hline Province dummies & yes & yes & yes & yes \\
\hline Constant & $0.654 *$ & $0.341 * * *$ & $0.255 * * *$ & $0.226 * *$ \\
\hline Number of obs. & 8788 & 17284 & 18877 & 17891 \\
\hline Adj. $R^{2}$ & 0.406 & 0.413 & 0.412 & 0.422 \\
\hline
\end{tabular}

Source: NBS urban household survey data

Note: the base groups are: female; high school graduates; state-owned companies; and government. Dependent variables are indicators of good occupation (i.e. professional, managerial, technical and clerical jobs) in the starting, $1^{\text {st }}, 3^{\text {rd }}$, and $5^{\text {th }}$ year. $* * * * * *$ indicate statistical significance at the 10,5 , and $1 \%$ level. 
References:

Appleton, S., Song, L. N., Xia, Q. J., 2005. Has China crossed the river? the evolution of wage structure in urban china during reform and retrenchment. Journal of Comparative Economics 33, 644663.

Autor, David H., Katz, Lawrence F., and Kearney, Melissa S. 2008. Trends in U.S. Wage Inequality: Revision the Revisionists. Review of Economics and Statistics 90(2):300-323.

Autor, David H., Katz, Lawrence F., and Kearney, Melissa S. 2005. Rising wage inequality: the role of composition and prices. NBER working paper 11628.

Baker, George, Gibbs, Michael, Holmstrom, Bengt, 1994. The wage policy of a firm. Quarterly Journal of Economics, 109(4): 921-55.

Bian, Yanjie. 1994. Guanxi and the Allocation of Urban Jobs in China. The China Quarterly, 140: 971999.

Beaudry, Paul and John DiNardo, 1991. The effect of implicit contracts on the movement of wages over the business cycle: Evidence from micro data. Journal of Political Economy, 99(4): 665-688.

Freeman, Richard B. 1981. Career patterns of college graduates in declining job markets, NBER Working Papers W0750.

Gao, X. 2007. Business cycle accounting for the Chinese economy. IDEAS working paper. http://ideas.repec.org/p/pra/mprapa/7050.html

Gong, G., Lin, Justin Yifu, 2008. Deflationary expansion: An overshooting perspective to the recent business cycle in China. China Economic Review, 19:1-17.

Imai, Hiroyuki, 1996. Explaining China's business cycles. The Developing Economies, XXXIV-2: 154185.

Kahn, Lisa B., 2006. The Long-Term Labor Market Consequences of Graduating from College in a Bad Economy(September 12, 2006). Available at SSRN: http://ssrn.com/abstract=702463

Knight, John, and Lina Song. 2003. Increasing Urban Wage Inequality in China: Extent, Elements and Evaluation. Economics of Transition, 11(4):597-619.

Oreopoulos, Phil, till von Wachter, Andrew Heisz, 2006. The short-and long-term career effects of graduating in a recession: hysteresis and heterogeneity in the market for college graduates, NBER Working papers W12159.

Oyer, Paul, 2006. Initial Labor market conditions and long term occupation for economists. Journal of Economic Perspectives, 20(3): 143-160.

Rauum, Oddbjorn and Knut RØed, 2006. Do business cycle conditions at the time of labor market entry affect future employment prospects? The Review of Economics and Statistics, 88(2):193-210. 
Wei, X., Li, W.L., Chen, D.F., 1997. Research on the current job allocation mechanism of college graduates. Journal of Higher Education, 1997(1): 31-37. (Chinese)

Zhang, Junsen; Zhao, Yaohui; Park, Albert; Song, Xiaoqing, 2005. Economic Returns to Schooling in Urban China, 1988 to 2001. Journal of Comparative Economics. 33,730-752. 